\title{
Determining Criteria and Their Weights for Evaluating the Capability of Gen-Z Human Resources Meeting Japanese Labour Market Expectations- A Case Study in Binh Dinh
}

\author{
Chuong M. Tran', Thang Q. Dao ${ }^{2}$, Linh P.V. Dao ${ }^{3}$, Kim M. Le ${ }^{4}$ \\ 1,2,3,4 Quy Nhon University
}

\begin{abstract}
The objective of this study is to determine the criteria and their weights for evaluate the quality of gen-z human resources in Binh Dinh province and their capability of satisfying the requirements of working in Japan and/or working for Japanese enterprises located in the province, using the expert method and the Analytic Hierarchy Process (AHP) method. The results showed that the satisfying capability of human resources should be evaluated under 12 criteria: Physical health, Life skills, Occupational competence, Education attainment, Foreign language literacy, Computer literacy, Self-discipline and self-organization, Work attitude, Problem-solving skills, Independent working skills, Teamwork skills, and Learning skills.
\end{abstract}

KEY WORDS: Criteria, weights of criteria, Japanese labour market, satisfying capability, human resources.

\section{INTRODUCTION}

Through a thorough literature review, the authors identified a fact that the Japanese work force is alarmingly aging (Lam Anh, 2020). The statistical data of Japan Ministry of Internal Affairs and Communications shows that by September 15, 2018, 20.7 percent of the Japanese population were 70 years old or above, an increase from 19.9 percent at the same period the previous year, and is expected to rise even faster in the future. Therefore, there has been an increasing demand for importing workers from foreign countries to solve the shortage of human resources in various sectors. Japan is one of the top countries in the list of foreign direct investment (FDI) in Binh Dinh province. Thus, there are great opportunities for the province's Gen-Z people either to work for Japanese enterprises in province or get exported to the large labour market in Japan. The demand is also expected to be expanded in the future. Despite the demand, however, it seems to be a fact that the Japanese government is not loosing its policy of importing foreign workers, and neither do Japanese enterprises to employ local people. They have instead strick stipulations regarding potential workers' health, ages, Japanese language literacy, and occupational competence in recruiting into enterprises or importing them into Japan's domestic labour market.

Therefore, it is urgently essential to investigate and evaluate the quality of the province's human manpower to make it informative for potential investors, manpower exporters, policy makers, and training agencies. Evidence-based results are required by the province's authority to build long-term plans as well as proper policies to boost the quality of this group of human resources as well as their suitability to this difficult pool of occupations, contributing greatly to Japanese investment attraction into Binh Dinh and to the increase of the number of qualified people exported to the aging country, leading to a stable rise of foreign currency income for the province's socio-economic development.

\section{LITERATURE REVIEW}

There have been emperical studies of investigation into the quality of human resources and their satisfying capability. These studies were carried out on varous groups of samples, in different scopes, and with different methods (see, for example, Cubas, 2016; Hoang Lan and Minh Hien, 2015; Minh Nhut, 2012; Jajri and Ismail, 2010; and Bolli and Zurlinden, 2009). A thorough review allows classifiying these emperical studies into two following groups.

\section{Studies in context of Vietnam}

Hoang Lan and Minh Hien (2015) evaluated the quality of training people from the lens of employers. The evaluation was based on a series of criteria proposed by the authors including workers' occupational competence and their work attitude required by the employers (holistically referred to as 'work skills'). These skills were divided into three groups: technical skills, perceptional 


\section{International Journal of Current Science Research and Review}

ISSN: 2581-8341

\section{Volume 04 Issue 04 April 2021}

DOI: 10.47191/ijcsrr/V4-i4-03, Impact Factor: 5.825

IJCSRR@ 2021

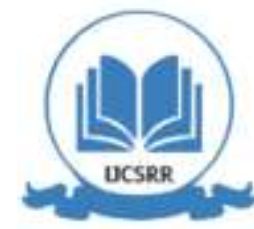

Www.ijcsrr.org

skills, and socio-behavioural skills. The study used three indexes: quality index, weighed quality index, and expected qualitysatisfying levels. The results from a survey administered in 386 companies show they considered the technical skills less important than the two other groups of skills. They also found that the employers admitted their workers as significantly low in practical skills such as technical-specific knowledge application skills, foreign language proficiency, creative-thinking ability, and work discipline.

Minh Nhut (2012) also measured the satisfaction of the Mekong Delta companies over the quality of university graduates. The studied used the Likert scale to measure the criteria of quality from the AUN standards, which is composed of 24 criteria such as the ability to applying general knowledge into doing tasks, independent work, teamwork, planning skill, communication skill, language and computer literacy, work discipline, professional responsibility, adaptiveness to changeable work environments, and so on. A desciptive statistical method and a t-test were used to analyze the collected data from the companies from 2011 . The results show that the quality of the targeted group of university graduates received significantly positive responses with a large number of them befitting the employer's expectations. However, these employers were dissatisfied under some of the specified criteria such as the graduates' ability to work independently, ability to work in team, and ability to negotiate at work.

Another noticiable study on evaluating the quality of human resources was conducted by Hong Lien (2015). She looked at the performance of the workers of Industrial Vinh Tuong Ltd. Company, so as to propose solutions to improve the quality of the company's labour effiency. The investigation was based on three quality criteria: Health (including both physical and mental health), intellectual abilities (including academic literacy, technical skills, and soft skills), and the workers' awareness. The study found that the majority of workers at Industrial Vinh Tuong Ltd. Company met these criteria and satisfied the task requirements of the company.

Similarly, Minh Thu \& Minh Du (2013) consctructed in their study an ability evaluation system, based on which they measured the abilities of staff at a training institution and proposed more suitable curricula. This system is composed of three categories. The first category is a specified ability dictionary composed of 39 specific abilities divided into 4 groups: knowledge (5 abilities), skills ( 21 abilities), attitudes ( 8 abilities), values ( 5 abilities). The second is a profile of abilites constructed for 10 different groups of tasks, which illustrate how 'general abilities' and 'minimum completion levels' to be fulfilled by workers responsible for responsive groups of tasks. The last category is a regulation of assessing abilities, instructing the process of evaluating the staff's abilities. The study found that in addition to the three groups of training programs which were proposed, it is necessary to launch new programs for 'specific professional abilities' for specified groups of tasks, fitting to the practical abilities of each individual worker.

Regarding training workers to work abroad, Sy Tuan (2012) investigated the improvement of human resources quality to meet Vietnam's demand of manpower export. The study yielded 9 criteria to evaluate the potentially-exported workers, including physical health, life skills and social knowledge, ability to work independently, and ability to work in teams. In addition, the study clarified seven factors affecting the quality of the potentially-exported workers: recruitment process, the development level of national education and local training, national and local policies, occupational culture, public health situation, local socio-economic development level, and workers' geological location.

\section{Studies in other countries}

Cubas (2016) analyzed the data from countries of different income levels to look at the correlation between labour efficiency and economic growth. The study constructed a labour efficiency measurement model for 59 countries in an approach totally different from the traditional methods, using the test results obtained from the Program for International Student Assessment (PISA). This means that direct observations of individual's performance before they enter the workforce is considered as a factor impacting the quality of workers. The results show that the labour efficiency in high-income countries doubles that in low-income countries.

Bolli and Zurlinden (2009) measured the growth of the labour quality and the unemployment rate adjusted for labor quality in Switzerland, by constructing a two-stage regression model for assessing labour efficiency. In the first stage, wages were used as a measure of productivity, and then a wage model was built based on workers' characteristics such as age, gender and education level. In the second stage, weights about working hour changes are constructed based on the wages predicted from the first stage, and the labor input indexes were adjusted for the given quality. The labour quality index was calculated by the labor input quality adjustment ratio divided by the number of working hours. The study found significant evidence of an annual increase of 0.5 percent in the labour quality index from 1991 and 2006. Given forecasts over the period 2006-2050 showed that growth in the labour quality would slow down over time, while the study also calculated the quality-adjusted unemployment rate and found that the unemployment rate decreases as human capital accumulation is taken into account. 


\section{International Journal of Current Science Research and Review}

ISSN: 2581-8341

Volume 04 Issue 04 April 2021

DOI: 10.47191/ijcsrr/V4-i4-03, Impact Factor: 5.825

IJCSRR@ 2021

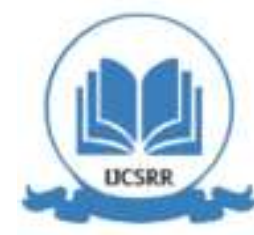

www.ijesrr.org

Hanushek and Kimko (2000) studied the relationships between education, the quality of the workforce and the growth of countries. The study refers directly to the measurement of the quality of the workforce, rather than focusing on the traditional measures such as education factors (spendings on education or the number of teachers). It contructed new quality assessment measures based on students' perceptions of various international tests in math and science. Discrepancies in the quality of the workforce measured in this way proved to have an extremely powerful effect on growth. The results showed that these descrepancies are critical to growth, and they are related to academic achievements, not necessarily dependent on resources for learning.

Jajri and Ismail (2010) measured the extent to which the Malaysian economy benefited from the country's education expansion. Production and productivity functions were estimated using independent variables such as the invested capital and the country's quality of human resources. Labor efficiency and education were used as indicators to measure the quality of labor. The data were collected from the figures released by government agencies and reports around the world from 1981 to 2007 . The study shows that the capital and capital-labor ratio plays a key role in the growth in economy and labor productivity in Malaysia. Effective labor (mentality) played an active role in determining economic growth but its contribution was less than physical labor. The article suggests that the country's education system must aim to improve the quality of the workforce both physically and intellectually.

A study by San et al. (2006) developed a set of labor quality indexes (LQI) in Taiwan by conducting 2 large-scale surveys of 1,000 large firms and 844 union leaders, to determine appropriate weights for each of the main factors. The study also searched for relevant statistics to calculate the weighted sum of 25 sub-indices to aggregate LQI for Taiwan manufacturing industries during the period of 1990 and 2000. The results show that, LQI is a reliable indicator to track the improvement of the quality of human resources. The LQI consists of seven main elements, which are: (1) education, (2) human resources training, (3) labor productivity, (4) workforce structure, (5) work safety and workers' health, (6) labor relations and work ethics, and (7) worker management models and quality of workers' livelihoods. The LQI includes variables that directly affect the quality of labor, such as education, training, health improvement and work relations, and additionally, variables such as the workforce structure to capture any possible changes in workforce composition.

From the above studies, the researchers found that there has been many empirical studies conducted domestically and internationally to develop sets of criteria and scales to evaluate the quality of human resources to meet the requirements of foreign businesses, serving the needs of labor export to target markets. The criteria serving the measurement of the quality of human resources in general include: physical health, academic qualification, education, foreign language proficiency, labor productivity, occupational skills, problem-solving skills, labour relation skills, work ethics and discipline awareness. However, the domestic studies mostly implemented the general assessment of workers around the country rather than providing an in-depth analysis of characteristics of workers. Meanwhile, it is clear that different geographical areas create different characteristics of workers as well as labour market differences.

\section{METHODOLOGY}

To conduct this study we first based on previous studies and second used the expert method to consult 22 experts about the right criteria for evaluating gen-Z people's satisfying Japanese labour market requirements. Of the 22 experts were 8 directors at Japanese companies, 6 state-agency managers, 4 managers in labour-training institutions, and 4 scientists. The results of the expert survey on evaluation criteria are presented as follows:

Table 1. Survey results on criteria for evaluating gen-Z people's satisfying Japanese labour market requirements

\begin{tabular}{|l|l|l|l|l|l|}
\hline $\begin{array}{l}\text { Criteria for evaluating gen-Z people's readiness } \\
\text { for Japanese labour markets }\end{array}$ & Coded & \multicolumn{2}{l|}{ Agree } & \multicolumn{2}{l|}{ Disagree } \\
\hline 1 On physical health (hight, weight, etc.) & AM1 & 22 & $100.00 \%$ & 0 & $0.00 \%$ \\
\hline 2 On life skills & AM2 & 16 & $72.73 \%$ & 6 & $27.27 \%$ \\
\hline 3 On occupational competence & AM3 & 22 & $100.00 \%$ & 0 & $0.00 \%$ \\
\hline 4. On education attainment & AM4 & 21 & $95.45 \%$ & 1 & $4.55 \%$ \\
\hline 5. On foreign language proficiency & AM5 & 19 & $86.36 \%$ & 3 & $13.64 \%$ \\
\hline 6. On computer literacy & AM6 & 17 & $77.27 \%$ & 5 & $22.73 \%$ \\
\hline 7. On self-discipline and self-organization & AM7 & 22 & $100.00 \%$ & 0 & $0.00 \%$ \\
\hline
\end{tabular}




\section{International Journal of Current Science Research and Review}

ISSN: 2581-8341

Volume 04 Issue 04 April 2021

DOI: 10.47191/ijcsrr/V4-i4-03, Impact Factor: 5.825

IJCSRR@ 2021

www.ijcsrr.org

\begin{tabular}{|l|l|l|l|l|l|}
\hline 8. On work attitude & AM8 & 22 & $100.00 \%$ & 0 & $0.00 \%$ \\
\hline 9. On problem-solving skills & AM9 & 16 & $72.73 \%$ & 6 & $27.27 \%$ \\
\hline 10. On independent working skills & AM10 & 18 & $81.82 \%$ & 4 & $18.18 \%$ \\
\hline 11. On teamwork skills & AM11 & 21 & $95.45 \%$ & 1 & $4.55 \%$ \\
\hline 12. On learning skills & AM12 & 19 & $86.36 \%$ & 3 & $13.64 \%$ \\
\hline
\end{tabular}

Source: synthesized by the authors from research results

From the results of the expert survey, most of the experts agreed with the 12 component criteria for measuring the satisfying capaility of gen- $Z$ human resources for the Japanese labour market expectations. Of these, 4 criteria received agreement by all of the surveyed experts, i.e. Physical health, Occupational competence, Self-discipline and self-organization, and Work attitude. Only 2 criteria received the least support, but at $72.73 \%$. All in all, the 12 criteria were agreed by over $70 \%$ of the experts in question, so we used this set of 12 criteria to evaluate the satisfying capability of gen-Z people for the Japanese labour market requirements.

After verifying the criteria, we used Saaty's (1980) AHP method to determine the weight for each of them. In order to employ the AHP method, we constructed an AHP hierachical tree on evaluating the readiness of gen- $\mathrm{Z}$ people for the Japanese labour markets as follows:

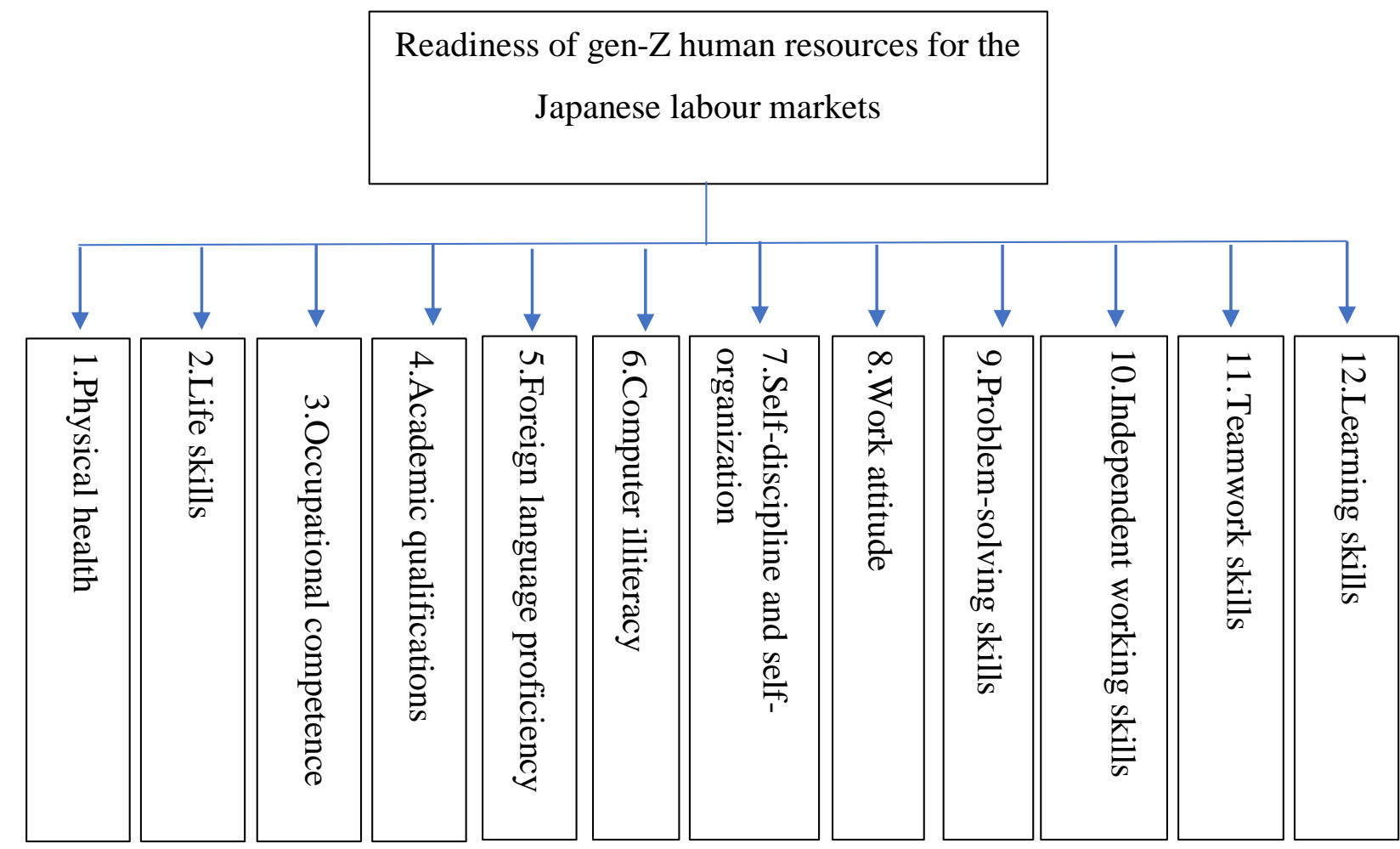

Figure 1. AHP hierachical tree to determing the weight of the criteria

Source: synthesized by the authors from research results

In the next stage, to determine the evaluation weight for each criterion we proceeded a group discussion with the 22 experts, who had participated in the survey in the previous stage. The discussion results allowed us to determine the rating scale of evaluating the relative importance of the evaluation criteria according to the principle of importance ranking. For example, there are 2 criteria to be evaluated: $\mathrm{X}$ and $\mathrm{Y}$, then the importance

Based on the results of group discussion, we determine the relative importance rating scale of the evaluation criteria according to the importance classification principle, for example: there are 2 criteria to be assessed: $\mathrm{X}$ and $\mathrm{Y}$; the rating scale of importance is determined as follows: 
ISSN: 2581-8341

Volume 04 Issue 04 April 2021

DOI: 10.47191/ijcsrr/V4-i4-03, Impact Factor: 5.825

IJCSRR@ 2021

www.ijesrr.org

Table 2. The rating scale of relative importance for the evaluation criteria

\begin{tabular}{|l|l|l|}
\hline Level(s) & Definition & Explanation \\
\hline 1 & Equally important & Factor A and factor B have equal contributions. \\
\hline 3 & Slightly more important & $\begin{array}{l}\text { Factor A is selected and paid more attention than factor B } \\
\text { in terms of contribution. }\end{array}$ \\
\hline 5 & More important & Factor A contributes more than factor B. \\
\hline 7 & $\begin{array}{l}\text { Very important and easy to realize the } \\
\text { difference in the impact }\end{array}$ & $\begin{array}{l}\text { Factor A contributes much more than B, clearly expressed } \\
\text { in specific cases. }\end{array}$ \\
\hline 9 & $\begin{array}{l}\text { Really important, completely dominant } \\
\text { factor A is of outstanding importance. The contribution of }\end{array}$ \\
\hline $2,4,6,8$ & Intervals between the levels above & There is a need for a compromise between the 2 factors. \\
\hline
\end{tabular}

Source: Saaty, 2008

Then, we built a matrix comparing the evaluation criteria based on the discussions of the experts by groups of expertise and the weights of the criteria were calculated as follows:

Table 3. Matrix of criteria according to the experts' opinions and weights

\begin{tabular}{|c|c|c|c|c|c|c|c|c|c|c|c|c|}
\hline $\begin{array}{l}\text { Evaluation } \\
\text { criteria }\end{array}$ & AM1 & AM2 & AM3 & AM4 & AM5 & AM6 & AM7 & AM8 & AM9 & AM10 & AM11 & AM12 \\
\hline & $\mathrm{a}$ & $\mathrm{b}$ & $\mathrm{c}$ & d & $\mathrm{e}$ & F & g & $\mathrm{h}$ & $\mathrm{i}$ & $\mathrm{j}$ & $\mathrm{k}$ & 1 \\
\hline AM1 & 1 & A1 & $\mathrm{A} 2$ & A3 & A4 & A5 & A6 & A7 & A8 & A9 & A10 & A11 \\
\hline AM2 & 1/A1 & 1 & B1 & B2 & B3 & B4 & B5 & B6 & B7 & B8 & B9 & B10 \\
\hline AM3 & 1/A2 & 1/B1 & 1 & $\mathrm{C} 1$ & $\mathrm{C} 2$ & C3 & $\mathrm{C} 4$ & C5 & C6 & C7 & $\mathrm{C} 8$ & C9 \\
\hline AM4 & 1/A3 & 1/B2 & $1 / \mathrm{C} 1$ & 1 & D1 & D2 & D3 & D4 & D5 & D6 & D7 & D8 \\
\hline AM5 & 1/A4 & 1/B3 & $1 / \mathrm{C} 2$ & 1/D1 & 1 & E1 & E2 & E3 & E4 & E5 & E6 & E7 \\
\hline AM6 & 1/A5 & 1/B4 & 1/C3 & 1/D2 & 1/E1 & 1 & $\mathrm{~F} 1$ & $\mathrm{~F} 2$ & $\mathrm{~F} 3$ & $\mathrm{~F} 4$ & F5 & F6 \\
\hline AM7 & 1/A6 & 1/B5 & $1 / \mathrm{C} 4$ & 1/D3 & 1/E2 & 1/F1 & 1 & G1 & G2 & G3 & G4 & G5 \\
\hline AM8 & $1 / \mathrm{A} 7$ & 1/B6 & $1 / \mathrm{C} 5$ & $1 / \mathrm{D} 4$ & 1/E3 & 1/F2 & 1/G1 & 1 & H1 & $\mathrm{H} 2$ & H3 & $\mathrm{H} 4$ \\
\hline AM9 & 1/A8 & 1/B7 & 1/C6 & 1/D5 & $1 / \mathrm{E} 4$ & 1/F3 & $1 / \mathrm{G} 2$ & 1/H1 & 1 & I1 & $\mathrm{I} 2$ & $\mathrm{I} 3$ \\
\hline AM10 & 1/A9 & 1/B8 & $1 / \mathrm{C} 7$ & 1/D6 & 1/E5 & $1 / \mathrm{F} 4$ & 1/G3 & $1 / \mathrm{H} 2$ & 1/I1 & 1 & $\mathrm{~J} 1$ & $\mathrm{~J} 2$ \\
\hline AM11 & 1/A10 & 1/B9 & 1/C8 & 1/D7 & 1/E6 & 1/F5 & $1 / \mathrm{G} 4$ & 1/H3 & 1/I2 & $1 / \mathrm{J} 1$ & 1 & K1 \\
\hline AM12 & 1/A11 & 1/B10 & 1/C9 & 1/D8 & $1 /$ E7 & 1/F6 & 1/G5 & $1 / \mathrm{H} 4$ & 1/I3 & $1 / \mathrm{J} 2$ & $1 / \mathrm{K} 1$ & 1 \\
\hline & $\sum_{a}^{n}$ & $\sum_{b}^{n}$ & $\sum_{c}^{n}$ & $\sum_{d}^{n}$ & $\sum_{e}^{n}$ & $\sum_{f}^{n}$ & $\sum_{g}^{n}$ & $\sum_{h}^{n}$ & $\sum_{i}^{n}$ & $\sum_{j}^{n}$ & $\sum_{k}^{n}$ & $\sum_{l}^{n}$ \\
\hline
\end{tabular}

Source: Saaty, 2008 


\section{International Journal of Current Science Research and Review}

ISSN: 2581-8341

Volume 04 Issue 04 April 2021

DOI: 10.47191/ijcsrr/V4-i4-03, Impact Factor: 5.825

IJCSRR@ 2021

Www.ijesrr.org

From this matrix, the consistency test consistency ratio (CR) to express the consistency of the experts in their discussion was calculated by

CR $<0.1(10 \%)$ which is suitable where

Consistency index $(C I)$, calculated by $C I=(\lambda \max -n)(n-1)$, where $n$ is the number of criteria and $\lambda$ max is the specific value of the comparison matrix.

The determined relationship between $\mathrm{CR}$ and $\mathrm{CI}$ is calculated by $\mathrm{CR}=\mathrm{CI} / \mathrm{RI}$, where $\mathrm{RI}$ is Random Index and is determined as presented in the following table.

\begin{tabular}{|c|c|c|c|c|c|c|c|c|c|c|c|c|c|c|c|}
\hline $\mathrm{N}$ & 1 & 2 & 3 & 4 & 5 & 6 & 7 & 8 & 9 & 10 & 11 & 12 & 13 & 14 & 15 \\
\hline RI & 0 & 0 & 0.52 & 0.89 & 1.11 & 1.25 & 1.35 & 1.4 & 1.45 & 1.49 & 1.52 & 1.54 & 1.56 & 1.58 & 1.59 \\
\hline
\end{tabular}

Source: Saaty, 2008

The process of determining the weight for each evaluation criteria and evaluation content is showed in the following figure.

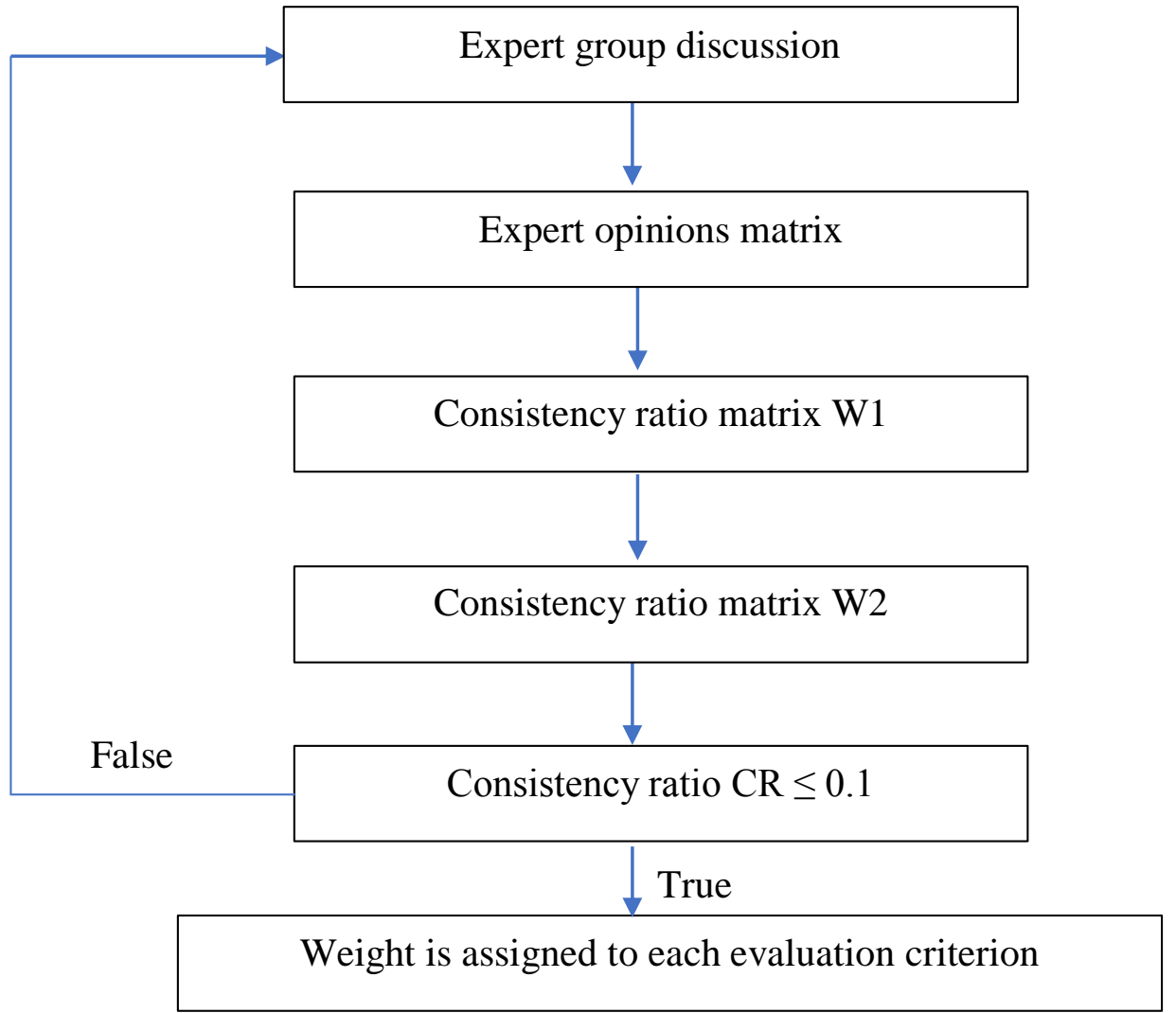

Figure 2. Process of determining the evaluation weights following the AHP method Source: Synthesized by the authors from research results

At the same time, based on the weights identified in the above step, the total score for each individual worker's readiness for Japanese labor markets is calculated with the following formulas:

$$
\mathrm{AM}=\sum_{i=1}^{12} A M i * P i(\%)
$$

where AM total score for each individual worker's readiness for Japanese labor markets; $\mathrm{AM}_{\mathrm{i}}$ is the score of each criterion obtained from the survey; and $\mathrm{P}_{\mathrm{i}}$ is the wight of $\mathrm{i}^{\text {th }}(\mathrm{i}=1,2, \ldots, 12)$ calculated from the AHP results. 


\section{International Journal of Current Science Research and Review}

ISSN: 2581-8341

Volume 04 Issue 04 April 2021

DOI: 10.47191/ijcsrr/V4-i4-03, Impact Factor: 5.825

IJCSRR@ 2021

www.ijesrr.org

\section{RESULTS}

4.1 Evaluation weights of the criteria

Applying the AHP method to calculate the weights of the criteria measuring the gen-Z people's readiness for the Japanese labour markets, yielding the following values:

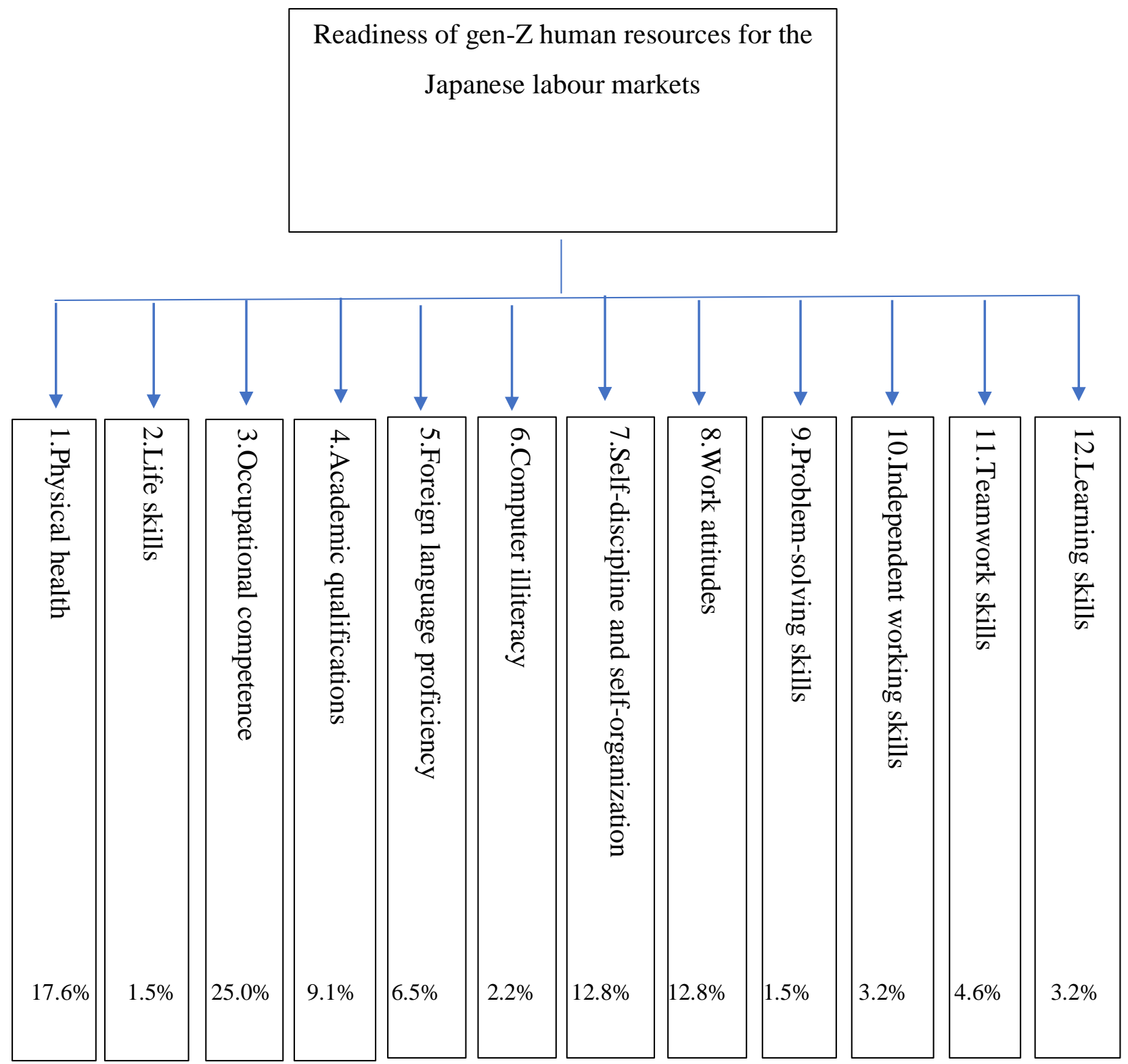

Figure 3. Evaluation weights of the criteria from the AHP analysis results

Source: synthesized by the authors from research results

With consistency ratio $\mathrm{CR}=0.03<0.1$, it is showed that the above results of determined weights are reliable. The results in Figure 3 show that the criterion of Occupational competence is of the greatest importance at $25 \%$, followed by Physical health at $17.6 \%$, Self-discipline and Working attitudes each accounting for $12.8 \%$, and the two criteria with the lowest weight are Problem-solving skills and Life skills each accounting for only $1.5 \%$. 


\section{International Journal of Current Science Research and Review}

ISSN: 2581-8341

Volume 04 Issue 04 April 2021

DOI: 10.47191/ijcsrr/V4-i4-03, Impact Factor: 5.825

IJCSRR@ 2021

www.ijesrr.org

\subsection{Demographic description of the surveyed participants}

Table 4. Demographic description of the surveyed participants

\begin{tabular}{|c|c|c|c|}
\hline \multicolumn{2}{|l|}{ Targets } & \multirow{2}{*}{$\begin{array}{c}\text { Number } \\
132\end{array}$} & \multirow{2}{*}{$\begin{array}{c}\text { Percentage } \\
33.0 \%\end{array}$} \\
\hline & Male & & \\
\hline Gender & Female & 268 & $67.0 \%$ \\
\hline \multirow{3}{*}{ Age } & $15-18$ & 27 & $6.8 \%$ \\
\hline & $19-25$ & 177 & $44.3 \%$ \\
\hline & 26 đến 30 & 196 & $49.0 \%$ \\
\hline \multirow{8}{*}{ Academic qualification } & Master or equivalent & 5 & $1.3 \%$ \\
\hline & Bachelor or equivalent & 55 & $13.8 \%$ \\
\hline & $\begin{array}{l}\text { Three-year diploma or } \\
\text { equivalent }\end{array}$ & 72 & $18.0 \%$ \\
\hline & $\begin{array}{l}\text { Two-year diploma or } \\
\text { equivalen }\end{array}$ & 19 & $4.8 \%$ \\
\hline & Baccalaureate & 121 & $30.3 \%$ \\
\hline & $\begin{array}{l}\text { Secondary school } \\
\text { leaver }\end{array}$ & 95 & $23.8 \%$ \\
\hline & Primary school leaver & 4 & $1.0 \%$ \\
\hline & No qualification & 29 & $7.3 \%$ \\
\hline \multirow{5}{*}{ Job position } & Manager & 33 & $8.3 \%$ \\
\hline & Office staff & 41 & $10.3 \%$ \\
\hline & Factory worker & 294 & $73.5 \%$ \\
\hline & Service worker & 6 & $1.5 \%$ \\
\hline & Others & 26 & $6.5 \%$ \\
\hline \multirow{4}{*}{ Avarage income per month } & $<4.4 \mathrm{~m}$ VND & 248 & $62.0 \%$ \\
\hline & $4.4-8 \mathrm{~m} \mathrm{VND}$ & 111 & $27.8 \%$ \\
\hline & $>8-11 \mathrm{~m} \mathrm{VND}$ & 17 & $4.3 \%$ \\
\hline & $>11 \mathrm{~m} \mathrm{VND}$ & 24 & $6.0 \%$ \\
\hline \multicolumn{2}{|l|}{ Total } & 400 & $100 \%$ \\
\hline
\end{tabular}

Source: synthesized by the authors from research results

Table 4 describes 400 employees of the $\mathrm{Z}$ generation working in Japanese enterprises in Binh Dinh province. It is noticed that female workers account for a large proportion (67\%). The majority of the surveyed workers are in the age range of from 18 to 30 years old, and nearly half of them are from 25 to 30 years old. In terms of academic qualification, those who have a baccalauriate, or graduating from high school, make up the largest percentage at 30\%. The respondents are mainly workers (73.5\%) with relatively low wages of below 4.4 million accounting for $62 \%$. This shows that the gen- $Z$ workers of Binh Dinh working in Japanese enterprises at present do not have high qualifications. This has a great influence on the responsiveness of the employees, and this is also likely to be the reason for their relatively low income.

\subsection{Current situation of Binh Dinh gen-Z workers' capability to satisfy Japanese labor market expectations}

The authors compile a statistic description of the 12 criteria for evaluating Binh Dinh gen-Z workers' ability to satisfy Japanese labor market needs based on the survey with 400 Binh Dinh gen-Z employees working in Japanese enterprises. The results are as follows: 


\section{International Journal of Current Science Research and Review}

ISSN: 2581-8341

Volume 04 Issue 04 April 2021

DOI: 10.47191/ijcsrr/V4-i4-03, Impact Factor: 5.825

IJCSRR@ 2021

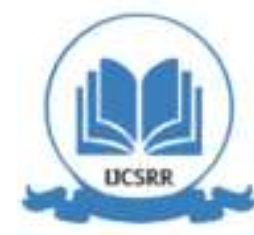

www.ijcsrr.org

Table 5. Statistical description of the criteria evaluating Binh Dinh gen-Z workers' ability to satisfy Japanese labor market needs

\begin{tabular}{|c|c|c|c|c|}
\hline Evaluation criteria & Mean & Min & Max & $\begin{array}{l}\text { Standard } \\
\text { Deviation }\end{array}$ \\
\hline 1. Physical health (hight, weight, etc.) & 3.34 & 5.0 & 1.0 & 0.95 \\
\hline 2. Life skills & 3.59 & 5.0 & 1.0 & 0.88 \\
\hline 3. Occupational competence & 3.44 & 5.0 & 2.0 & 0.53 \\
\hline 4. Education attainment & 3.06 & 5.0 & 1.0 & 0.86 \\
\hline 5. Foreign language proficiency & 2.53 & 4.0 & 1.0 & 0.61 \\
\hline 6. Computer literacy & 2.83 & 5.0 & 1.0 & 0.79 \\
\hline 7. Self-discipline and self-organization & 3.80 & 5.0 & 2.0 & 0.89 \\
\hline 8. Work attitude & 4.07 & 5.0 & 2.0 & 0.66 \\
\hline 9. Problem-solving skills & 3.51 & 5.0 & 1.0 & 0.88 \\
\hline 10. Independent working skills & 3.68 & 5.0 & 1.0 & 0.82 \\
\hline 11. Teamwork skills & 3.72 & 5.0 & 2.0 & 0.94 \\
\hline 12. Learning skills & 3.90 & 5.0 & 2.0 & 0.65 \\
\hline
\end{tabular}

Source: synthesized by the authors from research results

Looking at Table 5, it can be seen that most of the criteria are above 3.0, which means that most Binh Dinh employees who are working in Japanese enterprises in Binh Dinh or in Japan meet these markets' requirements at an average level. Out of the criteria, Foreign language proficiency and Computer literacy received the lowest average scores, at 2.53 and 2.83 respectively, corresponding to the negative satisfying level. This is understandable because up to $73.5 \%$ of the surveyed subjects were factory workers, leading to these two criteria are ranked at the bottom of the 12 criteria.

Among the above-average criteria, Worke attitudes was rated the highest with 4.07, corresponding to the workers' positive satisfying level to the requirements expected by the Japanese employers. Similarly, Self-discipline and self-organization was also rated at 3.8, roughly corresponding to the positive satisfying level. The average scores for these 2 criteria which were quite high show that the work attitude and awareness of the employees are a good. This is because for a long time, Vietnamese workers in general and especially low-level Vietnamese workers like those who were surveyed are often underestimated by foreign enterprises in terms of their work attitude.

The next most appreciated criteria were Learning skills with an average rating of 3.9, Teamwork skills at 3.72, and Independent working skills at 3.68. These three criteria received a higher scores than average, making it evident that Binh Dinh's gen- $Z$ workers are able to meet the requirements expected by Japanese employers at a higher level than average. Skills-related criteria also shared similar average score. Specifically, Life skills is at 3.59 Occupational skills at 3.44, and Problem-solving skills at 3.59. Thus, gen$\mathrm{Z}$ workers in Binh Dinh were evaluated in terms of skills as similarly above the average level. Physical health is also a very important criterion for Japanese employers. Compared to the other criteria, the gen- $Z$ workers in Binh Dinh are not as highly appreciated but they still achieve the average response level of 3.34 .

In another development, based on the weights calculated in Figure 3, the authors further calculated the total score to evaluate gen- $Z$ individual employees' ability to meet the Japanese labor market requirements, as showed in Table 6. 


\section{International Journal of Current Science Research and Review}

ISSN: 2581-8341

Volume 04 Issue 04 April 2021

DOI: 10.47191/ijcsrr/V4-i4-03, Impact Factor: 5.825

IJCSRR@ 2021

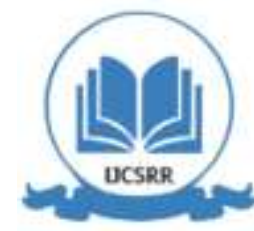

www.ijcsrr.org

Table 6. Total score to evaluate gen-Z individual employees' capability to satisfy the Japanese labor market requirements

\begin{tabular}{|l|c|c|c|c|}
\hline Evaluation criteria & Mean & Min & Max & $\begin{array}{c}\text { Standard } \\
\text { Deviation }\end{array}$ \\
\hline Requirement satisfying ability & 3.483 & 4.354 & 2.646 & 0.282 \\
\hline
\end{tabular}

Source: synthesized by the authors from research results

In general, each gen-Z worker in Binh Dinh is able to meet the requirements of the Japanese labor market, after weighing 3,483 , which is still higher than the average response level and shows not much deviation from the results of each criterion without weighting. From this result, the authors are confident to confirm Binh Dinh gen-Z workers' current ability to satisfy the Japanese labor market requirements is acceptable.

\section{CONCLUSION}

The study used the expert method combined with the AHP method to determine the weights to evaluate the responsiveness of genZ human resources in Binh Dinh on 12 criteria, i.e., Physical health, Life skills, Occpational competence, Education attainment, Foreign language proficiency, Computer literacy, Self-discipline and self-organization, Work attitude, Prolem-solving skills, Independent working skills, Teamwork skills, Learning skills. The results show that each criterion has a different level of importance. Specifically, the criterion of Occupational competence is of the greatest importance, at up to $25 \%$, followed by Physical health, accounting for $17.6 \%$, Self-discipline and self-organization and Work attitude each accounting for $12.8 \%$. The two criteria with the lowest weights are Probem-solving skills and Life skills, which account for only $1.5 \%$ each. This result is expected to be informative for young people and companies in the training and labor export industry towards the Japanese labour market. They can be informed which criteria are the most important and which ones are required by this market, leading to suitable education. This is definitely helpful in their improving the image of the province's human resources in the eyes of Japanese employers, which in turn improves job opportunities.

In addition, the study also described the current situation of the requirment satisfying levels of Binh Dinh gen- $Z$ workers who have worked for Japanese enterprises. The results show that Binh Dinh workers are able to meet the Japanese labour market requirements at the average level. In some of the criteria Binh Dinh employees responded at a good level, for example such prominent criteria as Work attitude, and Self-discipline and self-organization. This is a good point that young workers in Binh Dinh need to maintain and promote because "Self-discipline and self-organization" is one of the three most important criteria that Japanese employers appreciate. Although the two criteria Computer literacy and Foreign language proficiency are not as important criteria that employers are concerned, Binh Dinh gen-Z workers and training enterprises should be noticed of. If workers are better in these criteria, they are more likely to have better job opportunities in the future.

Finally, after calculating the weight for each of the criteria, combined with the evaluation score under each criterion, the study calculated the AM index for individual gen-Z employees in Binh Dinh (the total score for evaluating their ability to satisfy the Japanese labor market requirements). It can be concluded that, on average, each gen-Z employee in Binh Dinh currently has an above average response rate to the Japanese labor market requirements.

\section{ACKNOWLEDGEMENT}

The authors gratefully acknowledge the financial support from Binh Dinh Province People's Committee for research project code: 08-05-2019

\section{REFERENCES}

1. BOLLI, T. \& ZURLINDEN, M. 2009. Measuring growth of labor quality and the quality-adjusted unemployment rate in Switzerland. Applied Economics Quarterly, 55, 121.

2. BUI SY TUAN 2012. Enhancing the quality of human resources to meet the labor export demand of Vietnam until 2020. Doctoral thesis, National Economics University.

3. CUBAS, G., RAVIKUMAR, B. \& VENTURA, G. 2016. Talent, labor quality, and economic development. Review of Economic Dynamics, 21, 160-181. 


\section{International Journal of Current Science Research and Review}

ISSN: 2581-8341

Volume 04 Issue 04 April 2021

DOI: 10.47191/ijcsrr/V4-i4-03, Impact Factor: 5.825

IJCSRR@ 2021

www.ijesrr.org

4. HANUSHEK, E. A. \& KIMKO, D. D. 2000. Schooling, labor-force quality, and the growth of nations. American economic review, 90, 1184-1208.

5. HOANG LAN \& MINH HIEN 2015. Employers' assessment of the quality of higher education: A study of engineering technology sectors. VNU Journal of Science.

6. JAJRI, I. \& ISMAIL, R. 2010. Impact of labour quality on labour productivity and economic growth. African Journal of Business Management, 4, 486-495.

7. LAM ANH 2020. The pressure of aging population in Japan. Retrieved 122020 from https:/ /www.qdnd.vn/thoi-su-quocte/doi-song-quoc-te/suc-ep-dan-so-gia-o-nhat-ban-635966

8. MINH THU \& MINH DU 2013. Building and applying the staff capacity assessment system to propose appropriate training programs. Journal of Scien Ho Chi Minh Open University. No.1 (34) 2014.

9. SAATY, T. L. 1980. The Analytic Hierarchy Process. McGraw-Hill, New York.

10. SAATY, T. L. 2008. Decision making with the analytic hierarchy process. International journal of services sciences, 1, 8398.

11. SAN, G., HUANG, T.-C. \& HUANG, L.-H. 2006. The establishment and application of a labor quality index: The case of Taiwan's manufacturing industry. Social indicators research, 79, 61-96.

12. VU THI HONG LIEN 2015. Improving the quality of human resources at Lang Son's Social Insurance Agency. Doctoral thesis, University of labour and social affairs.

Cite this Article: Chuong M. Tran, Thang Q. Dao, Linh P.V. Dao, Kim M. Le(2021). Determining Criteria and Their Weights for Evaluating the Capability of Gen-Z Human Resources Meeting Japanese Labour Market Expectations-A Case Study in Binh Dinh. International Journal of Current Science Research and Review, 4(4), 254-264 